\title{
PEMETAAN VARIABEL-VARIABEL PEMBENTUK INDEKS DAYA SAING DAERAH MENGGUNAKAN METODE MICMAC
}

\section{MAPPING OF LOCAL COMPETITIVENESS INDEX VARIABLES USING MICMAC METHOD}

(disubmit 13 Januari 2021, direvisi 03 Mei 2021, diterima 01 Juni 2021)

\section{Hari Soesanto ${ }^{1}$}

${ }^{1}$ BPSDM Provinsi DKI Jakarta, Jalan Abdul Muis No. 66, Jakarta Pusat, DKI Jakarta

e-mail: hari.soesanto@jakarta.go.id

\begin{abstract}
ABSTRAK
Indeks daya saing daerah sebagai pembentuk indeks daya saing nasional sangat penting untuk diketahui oleh banyak pihak. Hal ini karena melalui indeks daya saing daerah dapat diketahui dimensi dan varibel yang memerlukan perhatian lebih. Saat ini, pemetaan indeks daya saing daerah sudah dilakukan oleh Kementerian Riset dan Teknologi pada tahun 2019 dengan 4 kategori dan 12 varibel. Dari pemetaan tersebut menghasilkan kesimpulan dimensi yang paling berpengaruh yaitu ekosistem inovasi. Penelitian ini bertujuan untuk melakukan pemetaan varibel-varibel yang mempengaruhi daya saing daerah dengan metode analisis MICMAC sebagai komparasi awal dari laporan yang sudah diterbitkan oleh Kementerian Riset dan Teknologi. Hasil penelitian mengindikasikan bahwa variabel kunci atau variabel penggerak yang menjadi pemicu daya saing daerah berkelanjutan yaitu terdiri dari dua variabel pada kategori faktor penguat, yaitu variabel kelembagaan dan infrastruktur; serta dua variabel pada kategori pasar yaitu variabel efisiensi pasar dan akses keuangan.
\end{abstract}

Kata Kunci: daya saing daerah, indeks daya saing, Micmac, variabel kunci

\begin{abstract}
The regional competitiveness index, which forms the national competitiveness index, is significant to be recognized by many parties because the regional competitiveness index can identify dimensions and variables that require more attention. At present, the mapping of the regional competitiveness index was carried out by the Ministry of Research and Technology in 2019, resulting in 4 categories and 12 variables. This mapping concludes that the most influential dimension is the innovation ecosystem. This study aims to map the variables that affect regional competitiveness using the MICMAC analysis method as an initial comparison of the Ministry of Research and Technology reports. The results indicated that the key variables or driving variables that trigger sustainable regional competitiveness consist of two variables: the reinforcing factor category (institutional and infrastructure variables) and two variables in the market category (market efficiency and financial access variables).
\end{abstract}

Keywords: competitiveness index, regional competitiveness, Micmac, key variable 


\section{PENDAHULUAN}

\section{World Economic Forum (WEF)} sebagai lembaga internasional yang melakukan pemeringkatan daya saing negara-negara sedunia menyatakan bahwa daya saing sebagai seperangkat lembaga, kebijakan, dan faktor-faktor yang menentukan tingkat produktivitas suatu negara (Schwab \& WEF, 2019). Lebih lanjut dalam laporan WEF tersebut dijelaskan bahwa pemeringkatan dilakukan berdasarkan pengukuran dari 12 pilar daya saing yang meliputi: institusi, infrastruktur, kondisi dan situasi ekonomi makro, kesehatan dan pendidikan dasar, pendidikan tingkat atas dan pelatihan, efisiensi pasar, efisiensi tenaga kerja, pengembangan pasar finansial, kesiapan teknologi, ukuran pasar, lingkungan bisnis, dan inovasi. Berdasarkan definisi dari WEF tersebut dapat juga terlihat bahwa daya saing suatu negara atau nasional merupakan agregat dari daerah atau wilayah pada negara tersebut.

Konsep daya saing daerah menurut definisi Departemen Perdagangan dan Industri Inggris (UK-DTI), lembaga yang secara rutin menerbitkan "Regional Competitiveness Indicators in United Kingdom" adalah kemampuan suatu daerah dalam menghasilkan pendapatan dan kesempatan kerja yang tinggi dengan tetap terbuka terhadap persaingan domestik dan internasional (Daryanto \& Hafizrianda, 2012). Lebih lanjut, Daryanto \& Hafizrianda (2012) menyatakan bahwa konsepsi daya saing terutama faktor-faktor penentu keunggulan daya saing wilayah mengikuti konsep yang dikemukakan oleh Porter (1990) dalam (Daryanto \& Hafizrianda, 2012), yaitu empat faktor pokok dan dua faktor penunjang. Empat faktor pokok yaitu kondisi faktor produksi, kondisi permintaan pasar, industri-industri terkait dan industri pendukung serta strategi perusahaan, struktur dan persaingan; sedangkan faktor penunjangnya adalah peluang dan peranan pemerintah.

Menurut Laporan Pemetaan Indeks Daya Saing Daerah (IDSD) se-Indonesia 2019 yang dikeluarkan oleh Kementerian Riset, Teknologi, dan Pendidikan Tinggi, IDSD diharapkan dapat menggambarkan kondisi dan kemampuan suatu daerah dalam mengoptimalkan seluruh potensi yang dimilikinya melalui peningkatan produktivitas, nilai tambah dan persaingan baik domestik maupun internasional demi kesejahteraan yang tinggi dan berkelanjutan. IDSD juga dapat diartikan sebagai refleksi tingkat produktivitas, kemajuan, persaingan dan kemandirian suatu daerah. Pentingnya IDSD sebagai alat untuk menilai keberhasilan suatu daerah untuk dapat bersaing dengan daerah lain dan mendukung daya saing nasional (Kemenristekdikti, 2019). Dengan kondisi otonomi daerah di Indonesia, maka IDSD merupakan salah wahana bagi pemerintahpemerintah daerah untuk berperan semaksimal mungkin meningkatkan daya saingnya, sehingga akan juga berdampak pada meningkatnya indeks daya saing nasional.

Penelitian mengenai daya saing sudah banyak dilakukan antara lain oleh (Berumen, 2005) antara lain dibahas mengenai hubungan antara teknologi, perdagangan, dan pertumbuhan ekonomi terhadap daya saing sebagaimana disajikan pada Gambar 1. 


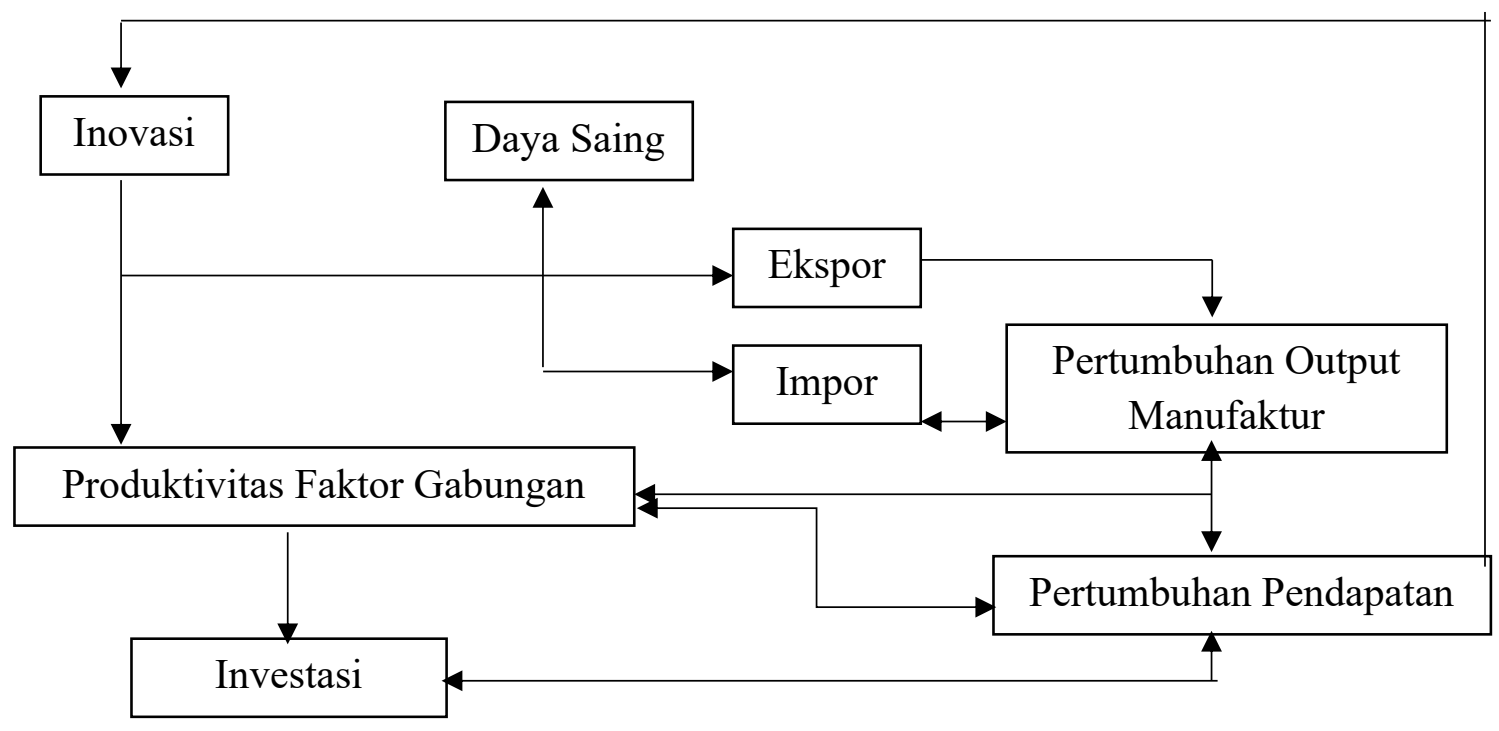

Gambar 1. Teknologi, Perdagangan, dan Pertumbuhan Ekonomi (Berumen, 2005)

\begin{tabular}{|c|c|}
\hline $\begin{array}{l}\text { Berdasarkan gambar } 1 \\
\text { arsebut terlihat bahwa daya saing } \\
\text { ipengaruhi oleh ekspor impor } \\
\text { berdagangan) dimana sebelumnya } \\
\text { erdagangan yang didukung oleh industri } \\
\text { helalui terobosan teknologi. Demikian } \\
\text { ula pertumbuhan ekonomi yang } \\
\text { tendorong terjadinya inovasi. Melalui } \\
\text { lovasi akan terjadi peningkatan } \\
\text { roduktivitas yang menimbulkan investasi, } \\
\text { an seterusnya. Selain itu penelitian } \\
\text { lengenai variabel-variabel yang berkaitan } \\
\text { engan daya saing daerah atau wilayah } \\
\text { lga telah diteliti oleh (Irawati, Urufi, } \\
\text { esobeoen, Setiawan, \& Aryanto, 2012) } \\
\text { aitu tingkat perekonomian daerah, } \\
\text { etersediaan infrastruktur dan sumber } \\
\text { aya alam, serta ketersediaan dan } \\
\text { ualitas sumber daya manusia. }\end{array}$ & $\begin{array}{l}\text { daerah juga bisa memperkuat daya saing di } \\
\text { tingkat yang lebih tinggi (nasional dan } \\
\text { global). Upaya dari berbagai daerah untuk } \\
\text { membina kerjasama antar daerah dalam } \\
\text { mempromosikan potensi daerah } \\
\text { (pemasaran daerah) merupakan salah satu } \\
\text { contoh pendekatan regional. (Andhyka, } \\
\text { 2019). Desain komponen indeks daya } \\
\text { saing daerah pernah dilakukan oleh } \\
\text { (Huggins, 2003) yaitu di negara United } \\
\text { Kingdom meliputi varibel: kepadatan } \\
\text { bisnis, pendapatan, bisnis berbasis } \\
\text { pengetahuan, produktivitas, partisipasi } \\
\text { ekonomi, dan pengangguran. Pengukuran } \\
\text { dan pemeringkatan daya saing di Peru juga } \\
\text { pernah dilakukan dengan menggunakan } \\
\text { metode Data Envelopment Analysis (DEA) } \\
\text { (Charles \& Zegarra, 2014). Charles \& } \\
\text { Zegarra (2014) menyarankan perlunya } \\
\text { pendekatan terpadu dalam membuat } \\
\text { strategi pembangunan dan meningkatkan } \\
\text { daya saing di seluruh wilayah Peru. Di } \\
\text { Meksiko, daya saing daerah dianalisis } \\
\text { dengan teknik penyortiran multi-kriteria } \\
\text { melalui model preferensi berbasis } \\
\text { ELECTRE (Fernandez, Navarro, Duarte, } \\
\text { \& Ibarra, 2013). }\end{array}$ \\
\hline
\end{tabular}


Salah satu metode yang dapat digunakan untuk mengetahui variabel kunci dari banyak variabel adalah metode MICMAC. Metode MICMAC adalah metode analisis struktural yang diperkenalkan pertama kali oleh Dupperin dan Michael Godet pada tahun 1973 untuk membuat peringkat elemen-elemen suatu sistem secara sistematis (Fauzi, 2019). Beberapa aplikasi metode MICMAC antara lain dilakukan untuk mengidentifikasi faktor-faktor kunci yang mempengaruhi keberlanjutan mata pencaharian pada komunitas pesisir (Paulus \& Fauzi, 2017). Identifikasi grafik kuadran ketergantungan-gaya penggerak terhadap keberlanjutan pada logistik $e$ commerce dilakukan menggunakan MICMAC (Jiang, Wang, Guo, \& Gong, 2019). Demikian pula faktor-faktor strategis kunci untuk memetakan sektor pertanian di Iran juga telah dilakukan dengan menggunakan metode MICMAC yang dikombinasikan dengan metode AHP (Barati, Azadi, Pour, Lebailly, \& Qafori, 2019).

Penelitian ini bertujuan untuk mengidentifikasi variabel-varibel kunci berkelanjutan yang membentuk IDSD sebagai komparasi awal dari laporan pemetaan indeks daya saing daerah yang dirilis oleh Kementerian Riset dan Teknologi tahun 2019. Walaupun penelitian ini masih sebatas langkah awal atau studi pendahuluan akan tetapi ingin memberikan alternatif metode dalam pemetaan variabel-variabel atau faktorfaktor yang mempengaruhi indeks daya saing daerah di Indonesia.

\section{METODE PENELITIAN}

Penelitian ini menggunakan pendekatan metode MICMAC (Matrix of Crossed Impact Multiplications Applied to a Classification). Metode ini dikembangkan oleh (Arcade, Godet, Meunier, \& Roubelat, 1999). Menurut (Fauzi, 2019), pendekatan MICMAC mengandalkan pemikiran analitis melalui pemecahan yang sistematis terhadap suatu masalah. Melalui MICMAC membantu untuk mengidentifikasi variabel-variabel yang bersifat mempengaruhi (influential) maupun dipengaruhi (dependent) yang penting bagi suatu sistem. MICMAC digunakan sebagai salah satu alat untuk analisis keberlanjutan, baik pada konteks sektoral maupun konteks kewilayahan.

Variabel-variabel yang diteliti pada penelitian ini merujuk pada Laporan Hasil Pemetaan Indeks Daya Saing Daerah (IDSD) se-Indonesia 2019 yang dirilis oleh Kementerian Riset dan Teknologi/Badan Riset Inovasi Nasional (BRIN) yaitu sebanyak 12 variabel yang termasuk dalam 4 kategori, seperti ditunjukkan di Tabel 1.

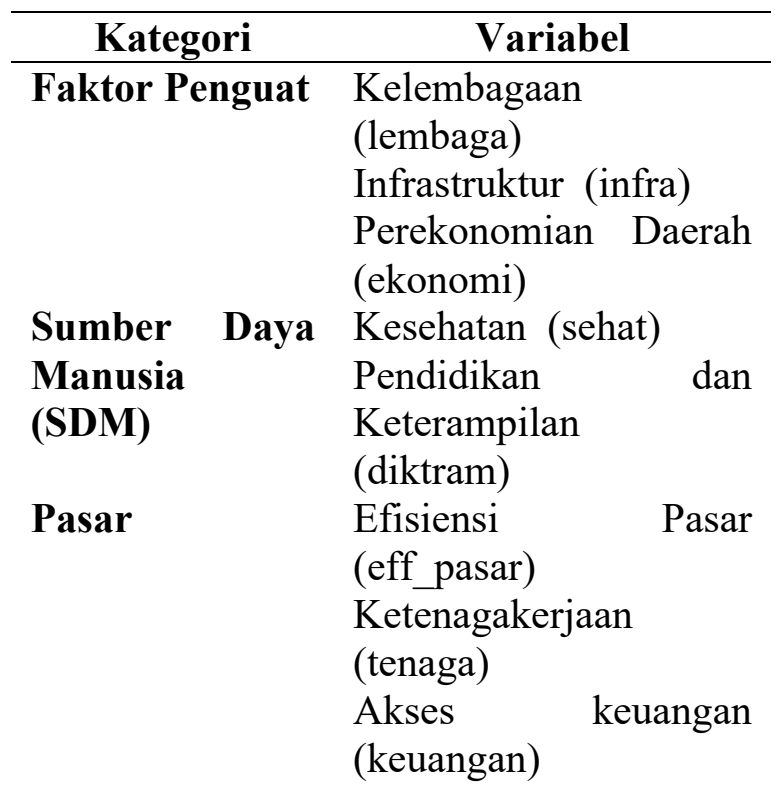




\begin{tabular}{llc}
\hline \multicolumn{1}{c}{ Kategori } & \multicolumn{2}{c}{ Variabel } \\
\hline & $\begin{array}{l}\text { Ukuran } \\
\text { (ukur_pasar) }\end{array}$ & Pasar \\
Ekosistem & $\begin{array}{l}\text { Dinamika } \\
\text { Inovasi }\end{array}$ & Bisnis \\
& $\begin{array}{l}\text { (Dinamika) } \\
\text { Kapasitas } \\
\text { (kap_ino) }\end{array}$ & Inovasi \\
& $\begin{array}{l}\text { Kesiapan } \\
\text { (siap_tekno) }\end{array}$ & Teknologi \\
&
\end{tabular}

Sumber: diolah dari Laporan Hasil Pemetaan Indeks Daya Saing Daerah se-Indonesia 2019 Kemenristek/BRIN (2020)

\section{HASIL DAN PEMBAHASAN}

Pada tahap awal setelah dilakukan penentuan variabel-variabel pembentuk indeks daya saing daerah berdasarkan informasi rujukan dari Laporan Hasil Pemetaan Indeks Daya Saing Daerah seIndonesia 2019 yang diterbitkan oleh Kemenristek/BRIN (2020). Selanjutnya proses analisis data melalui aplikasi MICMAC yaitu melalui konversi bobot tiap variabel pada IDSD ke dalam matriks pengaruh langsung (Matrix of Direct Influencel MDI) pada MICMAC sebagaimana disajikan pada Tabel 2. Semakin besar bobot variabel maka mengindikasikan semakin kuat pengaruhnya pada aplikasi MICMAC. Pengisian matriks pengaruh langsung mengikuti Godet (1994) dengan menggunakan skala 0 sampai 3 dan $\mathrm{P}$, dimana:

0 = tidak ada hubungan

$1=$ hubungan lemah

2 = rata-rata

$3=$ kuat

$\mathrm{P}=$ potential infulence
Tabel 2. Matriks dari Pengaruh Langsung

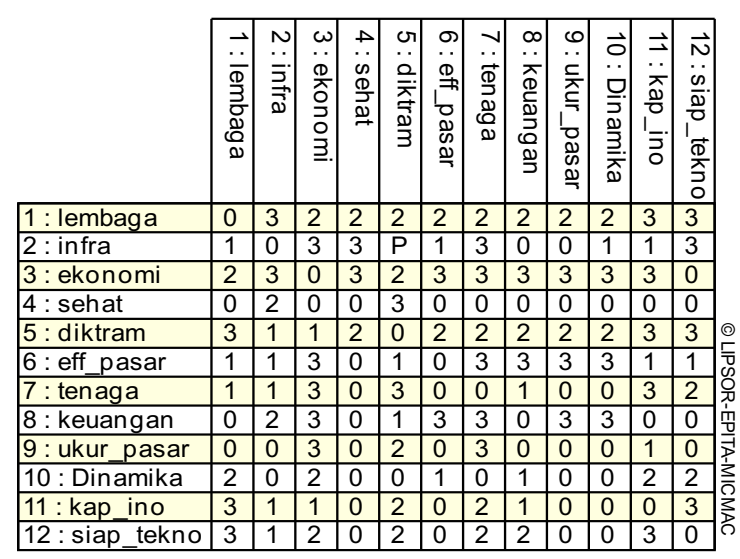

Dengan menggunakan aplikasi MICMAC berdasarkan Tabel 2, dihasilkan pemetaan variabel dalam bentuk Peta variabel daya saing daerah menurut pengaruh dan ketergantungan (Gambar 2).

Potential direct influence/dependence map

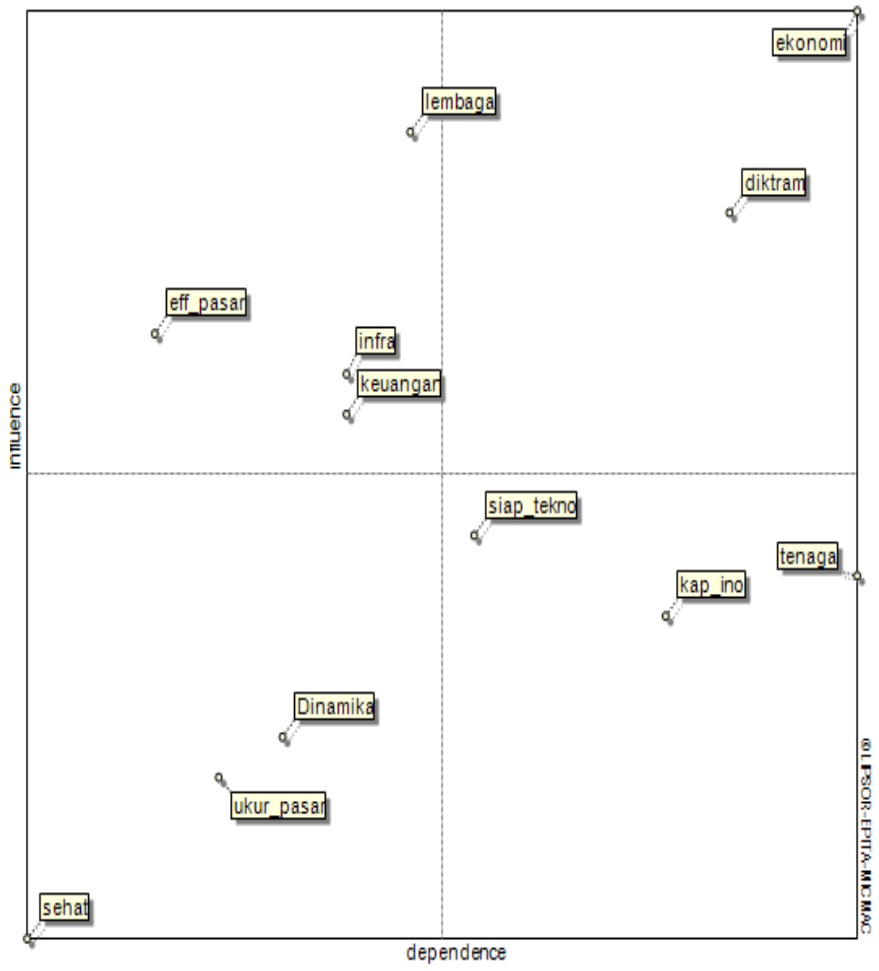

Gambar 2. Peta variabel keberlanjutan daya saing daerah menurut pengaruh dan ketergantungan

Berdasarkan Gambar 2 tampak bahwa variabel-variabel dari faktor penguat yaitu kelembagaan, infrastruktur, 
dan variabel-variabel dari pasar seperti efisiensi pasar, dan akses keuangan berada pada kuadran influence variable atau driver variable. Sementara variabelvariabel dari ekosistem inovasi seperti kesiapan teknologi, kapasitas inovasi, dan 1 variabel pasar yaitu ketenagakerjaan berada dalam kuadran dependent variable. Sedangkan pada kuadran autonomous terdiri dari dinamika bisnis, ukuran pasar, dan kesehatan. Selanjutnya, variabel perekonomian daerah dan pendidikan dan keterampilan berada di posisi relay variable.

Dari Gambar 2 tersebut juga terlihat bahwa dua indikator faktor penguat (kelembagaan, dan infrastruktur) serta dua indikator pasar (efisiensi pasar dan akses keuangan) merupakan empat indikator utama yang menjadi pemicu daya saing daerah berkelanjutan (variabel input atau driver), sedangkan dua indikator ekosistem inovasi (kesiapan teknologi dan kapasitas inovasi) dan satu indikator pasar (ketenagakerjaan) menjadi variabel terdampak dari variabel lainnya.

Perekonomian daerah dan pendidikan keterampilan berada dalam kuadran relay variable yang menunjukkan bahwa variabel ini sangat sensitif dan sangat tidak stabil dalam membangun daya saing daerah berkelanjutan karena intervensi apa pun pada variabel ini akan berdampak pada sistem secara keseluruhan. Dalam peta pada Gambar 2 juga terlihat bahwa variabel SDM seperti kesehatan merupakan variabel yang pengaruhnya relatif kecil terhadap sistem daya saing daerah.

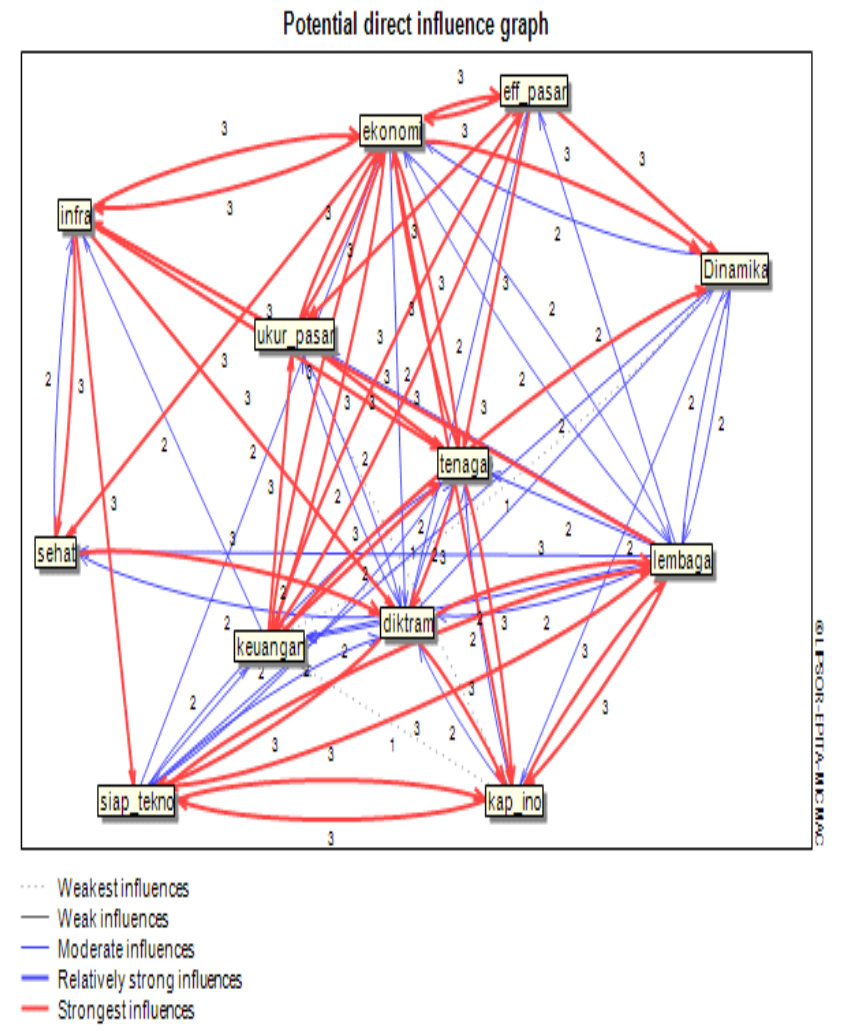

Gambar 3. Hubungan pengaruh langsung antar variabel keberlanjutan

Beberapa variabel yang terlihat pada Gambar 3 seperti perekonomian daerah, akses keuangan, dan kelembagaan memiliki pengaruh yang kuat terhadap variabel lainnya yang ditunjukkan dengan garis yang tebal dan arah panah keluar. Sementara variabel seperti dinamika bisnis, kapasitas inovasi, dan ukuran pasar dipengaruhi sangat kuat oleh variabel lain (arah panah menuju variabel tersebut).

Classify variables according to their influences

\begin{tabular}{|c|c|c|}
\hline Rank & Variable & Variable \\
\hline 1 & 3 - ekonomi & 3 - ekonomi \\
\hline 2 & 1 - lembaga & 1 - lembaga \\
\hline 3 & 5 - diktram & 5 - diktram \\
\hline 4 & 6 - eff_pasar & 6 - eff_pasar \\
\hline 5 & 8 - keuangan & 8 - keuangan \\
\hline 6 & 2 - infra & 12 - siap_tekno \\
\hline 7 & 12 - siap_tekno & 7 - tenaga \\
\hline 8 & 7 - tenaga & 2 - infra \\
\hline 9 & 11 - kap_ino & 11 -kap_ino \\
\hline 10 & 10 - Dinamika & 10 - Dinamika \\
\hline 11 & 9 - ukur_pasar & 9 - ukur_pasar \\
\hline 12 & 4 - sehat & 4 - sehat \\
\hline
\end{tabular}




\section{Classement par dépendance}

\begin{tabular}{|c|c|c|}
\hline Rank & Variable & Variable \\
\hline 1 & 3 - ekonomi & 7 - tenaga \\
\hline 2 & 7 - tenaga & 3 -ekonomi \\
\hline 3 & 11 - kap_ino & 11 -kap_ino \\
\hline 4 & 5 - diktram & 5 - diktram \\
\hline 5 & 12 - siap_tekno & 12 - siap_tekno \\
\hline 6 & 1 - lembaga & 1 - lembaga \\
\hline 7 & 2 - infra & 8 -keuangan \\
\hline 8 & 8 -keuangan & 2 - infra \\
\hline 9 & 10 - Dinamika & 10 - Dinamika \\
\hline 10 & 9 -ukur_pasar & 9 -ukur_pasar \\
\hline 11 & 6 - eff_pasar & 6 - eff_pasar \\
\hline 12 & 4 - sehat & 4 - sehat \\
\hline
\end{tabular}

Gambar 4. Peringkat variabel berdasarkan influence dan dependence

Pada Gambar 4 menunjukkan perubahan peringkat variabel indeks daya saing daerah berdasarkan pengaruh (influence) dan ketergantungan (dependence). Jika dilihat dari aspek dependence (ketergantungan), tiga variabel utama yaitu perekonomian daerah, ketenagakerjaan, dan kapasitas inovasi ada potensi pergeseran variabel yaitu variabel ekonomi menurun peringkatnya sebanyak satu tingkat dari urutan ke-1 menjadi urutan ke-2, sementara variabel ketenagakerjaan meningkat satu tingkat dari urutan ke-2 menjadi urutan ke-1 setelah iterasi MDII.

\section{KESIMPULAN DAN SARAN}

Berdasarkan temuan penelitian ini terdapat empat jenis variabel pembentuk indeks daya saing daerah yaitu driver variable, relay variable, autonomous variable, dan dependent variable yang terpetakan dalam peta empat kuadran melalui metode MICMAC. Dengan menggunakan metode MICMAC ini, variabel-variabel yang telah diidentifikasi dapat membantu sebagai bahan perbandingan (komparasi) dari pemetaan variabel-variabel indeks daya saing daerah yang telah dirilis oleh Kemenristek/BRIN. Key variable atau driver variable yang menjadi pemicu daya saing daerah berkelanjutan yaitu terdiri dari dua variabel pada kategori faktor penguat, yaitu variabel kelembagaan dan infrastruktur; serta dua variabel pada kategori pasar, yaitu variabel efisiensi pasar dan akses keuangan.

Akan tetapi terdapat limitasi pada penelitian ini yaitu validitas dan reliabilitas temuan penelitian perlu diperiksa ulang melalui penelitian lanjutan karena ada potensi hasil yang berbeda dengan pengisian nilai skor matriks MDI pada situasi dan waktu yang berbeda. Meskipun demikian, hasil penelitian ini diharapkan menjadi informasi awal bahwa variabelvariabel pembentuk indeks daya saing daerah di Indonesia dapat diuji komparasi dengan metode-metode lainnya.

\section{REFERENSI}

Andhyka, M. (2019). The Development of Region Learning Concept in Increasing Regional Competitiveness. Eurasia: Economics \& Business, 2(20), 113-124.

Arcade, J., Godet, M., Meunier, F., \& Roubelat, F. (1999). Structural analysis with the MICMAC method \& Actor's strategy with MACTOR method. Futures Research Methodology, American Council for the United Nations University: The Millennium Project, 1-49. 
Barati, A. A., Azadi, H., Pour, M. D., Lebailly, P., \& Qafori, M. (2019). Determining Key Agricultural Strategic Factors using AHPMICMAC. Sustainability, 11(14), 3947.

Berumen, S. A. (2005). An approach to local and regional competitiveness. Cuadernos de Administración, 18(29), 13-32. Diambil kembali dari http://www.scielo.org.co/scielo.p hp? script $=$ sci_arttext\&pid $=\mathrm{S} 0120$ $35922005000100002 \& \operatorname{lng}=\mathrm{en} \& \mathrm{tl}$ $\mathrm{ng}=\mathrm{en}$

Charles, V., \& Zegarra, L. F. (2014). Measuring regional competitiveness through Data Envelopment Analysis: A Peruvian case. Expert Systems with Applications, 41(11), 53715381.

Daryanto, A., \& Hafizrianda, Y. (2012). Model-Model Kuantitatif untuk Perencanaan Pembangunan Daerah: Konsep dan Aplikasi. Bogor: IPB Press.

Fauzi, A. (2019). Teknik Analisis Keberlanjutan. Jakarta: Gramedia Pustaka Utama.

Fernandez, E., Navarro, J., Duarte, A., \& Ibarra, G. (2013). Core: A decision support system for regional competitiveness analysis based on multi-criteria sorting. Decision Support Systems, 54(3), 1417-1426.

Huggins, R. (2003). Creating a UK Competitiveness Index: Regional and Local Benchmarking. Regional Studies, 37(1), 89-96.

Irawati, I., Urufi, Z., Resobeoen, R., Setiawan, A., \& Aryanto. (2012). Pengukuran Tingkat Daya Saing Daerah Berdasarkan Variabel Perekonomian Daerah, Variabel Infrastruktur Dan Sumber Daya Alam, Serta Variabel Sumber Daya Manusia Di Wilayah
Provinsi Sulawesi Tenggara. J@TI Undip, VII(1), 43-50.

Jiang, X., Wang, H., Guo, X., \& Gong, X. (2019). Using the FAHP, ISM, and MICMAC Approaches to Study the Sustainability Influencing Factors of the Last Mile Delivery of Rural ECommerce Logistics. Sustainability, 11(14), 3937.

Kemenristekdikti. (2019). Laporan Pemetaan Indeks Daya Saing Daerah (IDSD) se-Indonesia 2019. Jakarta: Kementerian Riset, Teknologi, dan Pendidikan Tinggi.

Paulus, C. A., \& Fauzi, A. (2017). Factors Affecting Sustainability of Alternatives Livelihood in Coastal Community in Nembrala, East Nusa Tenggara: an Application of MICMAC Method. Jurnal Ekonomi Pembangunan, 175-182.

Schwab, K., \& WEF. (2019). The Global Competitiveness Report 2019. Geneva: World Economic Forum. 